\title{
Assessment of genetic diversity of Bacillus spp. isolated from eutrophic fish culture pond
}

\author{
R. Sen $\cdot$ S. Tripathy $\cdot$ S. K. Padhi $\cdot$ S. Mohanty $\cdot$ \\ N. K. Maiti
}

Received: 7 February 2014/ Accepted: 5 June 2014/Published online: 2 July 2014

(c) The Author(s) 2014. This article is published with open access at Springerlink.com

\begin{abstract}
The genus Bacillus comprises of a diverse group with a wide range of nutritional requirements and physiological and metabolic diversity. Their role in nutrient cycle is well documented. 16S rDNA sequences do not always allow the species to be discriminated. In this study 40 Bacillus spp. obtained from fish culture pond and 10 culture type strains were analysed for their genomic diversity by PCR-RFLP of intergenic spacer region of $16 \mathrm{~S}$ $23 \mathrm{~S}$ and HSP60 genes. TaqI digestion of PCR products amplified by ITS PCR did not render distinctive RFLP patterns. Numerical analysis of ITS PCR-RFLP pattern differentiated the isolates into 11 clusters. Same species were found to be grouped in different clusters. But PstI digested PCR products amplified from HSP60 gene of the isolates showed distinctive RFLP patterns. The dendrogram constructed from HSP60 PCR-RFLP delineated the isolates into 11 clusters also. All the clusters, except cluster I grouped only one type of species. The results showed that Bacillus spp. could be clearly distinguished by PCR-RFLP of HSP60 gene. Therefore, the HSP60 gene is proposed as an additional molecular marker for discrimination of Bacillus group.
\end{abstract}

Keywords Molecular marker - HSP60 gene · ITS · PCR-RFLP · Bacillus group

R. Sen $\cdot$ S. Tripathy $\cdot$ S. K. Padhi $\cdot$ S. Mohanty

N. K. Maiti $(\square)$

Microbiology Unit, Division of Fish Health Management, Central Institute of Freshwater Aquaculture, Kaushalyaganga, Bhubaneswar 751002, Orissa, India

e-mail: maitink@yahoo.co.in

\section{Introduction}

It is generally accepted that the mechanism of mineral phosphate solubilisation by phosphate solubilising bacteria (PSB) strains is associated with the release of low molecular weight organic acids which through their hydroxyl and carboxyl groups chelate the cations bound to phosphate, thereby converting it into soluble forms (Chen et al. 2006). Bacillus spp. has been identified to be the most effective agent in the process (Banik and Ninawe 1988), which has been clearly demonstrated in aquatic systems with rock phosphate as an insoluble source of Phosphate (Sahu and Jana 2000). The identification of microbial species by phenotypic methods can sometimes be uncertain, complicated and time-consuming. The use of molecular methods has revolutionised their identification, by improving the quality and effectiveness of this identification (Dellaglio et al. 1991). In prokaryotes, the $16 \mathrm{~S}$ ribosomal RNA (rRNA) genes are essential and occur in at least one copy in a genome. The universality of the genes makes them an ideal target for phylogenetic studies and taxonomic classification. 16S rRNA sequence analyses revealed the presence of several phylogenetically distinct lineages within the genus Bacillus (Yoon et al. 2003). However, the intergenic transcribed spacer regions (ITS), located between the 16S and 23S (ITS-1) and 23S and 5S (ITS-2) ribosomal genes, are thought to be under less evolutionary pressure and, therefore, may provide greater genetic variation than rRNA genes. These characteristics make ITS regions a potentially valuable tool for taxonomic and typing purposes, and their use as such has received increased attention (Osorio et al. 2004). Thus, Restriction fragment length polymorphism of ITS PCR (ITS PCR RFLP) has been used for differentiation of species and strains (Gurtler and Stanisich 1996). Although 16S rRNA molecule is most 
commonly accepted to distinguish genera and species, one fact that has been overlooked is that multiple copies of this gene are often present in a given bacterium. These intragenomic copies can differ in sequence, leading to identification of multiple ribotypes for a single organism. Alternative core housekeeping genes have to be used to complement the information provided by $16 \mathrm{~S}$ rRNA gene (Acinas et al. 2004). In this study, we examined the genetic relationship of Bacillus spp. based on PCR-RFLP profile of HSP60 gene and compared with ITS PCR RFLP in order to evaluate the use of an alternative gene as a marker for molecular microbial ecology.

\section{Materials and methods}

Isolation of bacillus spp.

Twenty sediment samples from carp rearing ponds were collected from uppermost layer at a depth of $4-5 \mathrm{~cm}$. The size of the rearing ponds was $0.1-0.4$ hectares. Alkalinity, $\mathrm{pH}$ and DO were $100-120 \mathrm{ppm}, 7.5-8.0$ and $4-5 \mathrm{mg} / \mathrm{l}$, respectively. A $10 \%$ sediment suspension in sterile Normal Saline Solution was boiled at $80{ }^{\circ} \mathrm{C}$ for $15 \mathrm{~min}$ in a rotary shaker bath at $50 \mathrm{rpm} / \mathrm{min}$. Ten fold serially diluted samples were spread over Nutrient Agar (HIMEDIA, India) plates. The plates were incubated at $37^{\circ} \mathrm{C}$ for $24 \mathrm{~h}$. Morphologically distinct colonies were stained for Gram reaction and endospore for tentative identification of Bacillus spp. Ten ATCC strains including Bacillus subtilis (ATCC 11774 and ATCC 6051), Bacillus cereus (ATCC13061 and ATCC 11778), Bacillus pumilus (ATCC 14884), Bacillus megaterium (ATCC14580 and ATCC 9885), Bacillus thuringiensis (ATCC 10792) and Bacillus licheniformis (ATCC14780 and ATCC 12759) were used in this study.

\section{DNA extraction}

Genomic DNA was extracted following method of Schmalenberger et al. (2001) with little modification. Overnight Nutrient broth cultures at $37{ }^{\circ} \mathrm{C}$ were pelleted by centrifugation at 5,000 rpm for $10 \mathrm{~min}$ and suspended in solution I (TE buffer), solution II $(1.25 \mathrm{ml}$ of $1 \mathrm{~N}$ $\mathrm{NaOH}+0.5 \mathrm{ml} 10 \%$ SDS $+3.25 \mathrm{ml}$ distilled water). Following addition of $20 \mu \mathrm{l}$ of Lysozyme $(20 \mathrm{mg} / \mathrm{ml})$, the cells were incubated at $37{ }^{\circ} \mathrm{C}$ for $30 \mathrm{~min}$. Cells were then lysed by boiling for $15 \mathrm{~min}$ and extracted with equal volume of phenol and chloroform: isoamyl alcohol (24:1). The final aqueous phase was made $0.3 \mathrm{M}$ in sodium acetate and DNA was precipitated by adding equal volume of isopropanol. Following centrifugation at $10,000 \mathrm{rpm}$ for $10 \mathrm{~min}$, the pellet was washed with $70 \%$ ethanol, dried, dissolved into $50 \mu \mathrm{l}$ distilled water and stored at $-20{ }^{\circ} \mathrm{C}$.
Amplification 16S-23S (ITS PCR) region

DNA spacer region between the 16S-23S ITS region was amplified by polymerase chain reaction (Clementino et al. 2001). Fifty microlitre of the reaction mixture contained $1 \mu \mathrm{l}$ of template DNA (100 ng), $5 \mu \mathrm{l}$ of $10 \mathrm{X}$ assay buffer (1.5 mM $\mathrm{MgCl}_{2}, 50 \mathrm{mM} \mathrm{KCl}, 20 \mathrm{mM}$ Tris-HCl, $\mathrm{pH} 8.0$, and $0.01 \%$ gelatin), $2 \mu \mathrm{l}(20 \mathrm{pmol})$ of forward primer $\left(5^{\prime}\right.$ CAAGGCATCCACCGT- $\left.3^{\prime}\right), 2 \mu \mathrm{l}(20 \mathrm{pmol})$ of reverse primer ( $5^{\prime}$-GAAGTCGTAACAAGG-3') $100 \mu \mathrm{M}$ each of dNTP master mix, $0.25 \mu \mathrm{l}$ of Taq DNA polymerase (0.75U, Bangalore Genei, India). The PCR was carried out using a thermal cycler (M. J. Research, Inc., Waltham, Massachusetts, USA) with initial denaturation of $94^{\circ} \mathrm{C}$ for $45 \mathrm{~s}$ followed by 30 cycles of denaturation at $94^{\circ} \mathrm{C}$ for $15 \mathrm{~s}$, annealing at $53{ }^{\circ} \mathrm{C}$ for $30 \mathrm{~s}$, extension at $72{ }^{\circ} \mathrm{C}$ for $1.5 \mathrm{~min}$ and a final extension at $72^{\circ} \mathrm{C}$ for $5 \mathrm{~min}$.

Amplification of HSP60 gene

PCR amplification was carried out using degenerate forward primer (5'-GGNCCNAARGGNA(C)GNAAYGT-3') and a degenerate reverse primer (5'-TCNCCRAANCCNG GNGCYTTNACNGC-3') as per the method of Rusanganwa et al. (1992). The PCR amplification was performed with a $50 \mu \mathrm{l}$ of volume including $5 \mu \mathrm{l}$ of $10 \mathrm{X}$ assay buffer $\left(1.5 \mathrm{mM} \mathrm{MgCl}_{2}, 50 \mathrm{mM} \mathrm{KCl}, 20 \mathrm{mM}\right.$ Tris-Cl, $\mathrm{pH}$ 8.0, and $0.01 \%$ gelatin), $1.5 \mathrm{mM} \mathrm{MgCl} 2,100 \mathrm{mM}$ (each) deoxynucleoside triphosphate (dNTP), $100 \mathrm{ng}$ of genomic DNA, 0.75 U of Taq DNA polymerase (Bangalore Genei), and 20 pmol of each of the degenerate HSP60 primers. The PCR was carried out with initial denaturation of $94^{\circ} \mathrm{C}$ for 5 min followed by 35 cycles of denaturation at $94{ }^{\circ} \mathrm{C}$ for $30 \mathrm{~s}$, annealing at $56{ }^{\circ} \mathrm{C}$ for $30 \mathrm{~s}$, extension at $72{ }^{\circ} \mathrm{C}$ for $1 \mathrm{~min}$ and a final extension at $72{ }^{\circ} \mathrm{C}$ for $7 \mathrm{~min}$.

\section{PCR-RFLP}

Ten microliter of HSP60 PCR product was digested with $2 \mathrm{U}$ of PstI (New England Biolabs) using appropriate assay buffer at $37{ }^{\circ} \mathrm{C}$ overnight. Restriction digestion of 16S-23S ITS PCR product was performed at $65{ }^{\circ} \mathrm{C}$ overnight using $10 \mu \mathrm{l}(1 \mu \mathrm{g})$ of amplified PCR product, $2 \mathrm{U}$ of enzyme TaqI (New England Biolabs) and appropriate assay buffer.

16S rDNA sequencing and identification

The 16S rDNA gene from individual bacterial isolates was amplified by polymerase chain reaction (Stanley et al. 1995). The forward primer was $5^{\prime}$ AAG AGT TTG ATC CTG GCT CAG $3^{\prime}$ and the reverse primer was $5^{\prime}$ GGT TAC ATT GTT ACG ACT T. The PCR reaction mixture $(50 \mu \mathrm{l})$ contained, dNTPs each $100 \mu \mathrm{mol} ; 1 \mathrm{X}$ PCR buffer 
(10 mMTrisCl, $50 \mathrm{mMKCl}, 2.5 \mathrm{mM} \mathrm{MgCl}_{2}$ and $0.01 \%$ gelatin); each primer $20 \mathrm{pmol}$; Taq DNA polymerase (Genei, India) $0.75 \mathrm{U}$ and bacterial DNA $100 \mathrm{ng}$. The PCR in a volume of $50 \mu \mathrm{l}$ was carried out with initial denaturation of $94{ }^{\circ} \mathrm{C}$ for $5 \mathrm{~min}$ followed by 35 cycles of denaturation at $94{ }^{\circ} \mathrm{C}$ for $1 \mathrm{~min}$, annealing at $49{ }^{\circ} \mathrm{C}$ for $2 \mathrm{~min}$, extension at $72{ }^{\circ} \mathrm{C}$ for $2 \mathrm{~min}$ and a final extension at $72{ }^{\circ} \mathrm{C}$ for $8 \mathrm{~min}$. PCR product was purified by using the QIAquick PCR purification kit according to the manufacturer's instructions (QIAGEN, Germany) and sequenced (Chromous Biotech, Chennai, India). A database search was performed using BLAST programme (NCBI, Maryland, USA) to identify the microorganisms at species level.

Data analysis

Following background correction, phylogenetic analysis was performed using Visionworks ${ }^{\circledR}$ Life Science Software. For phylogenetic study of this data matrix consisting of ITS PCR-RFLP and HSP60 PCR-RFLP profile data were transformed to estimate distances (Nei and Li 1979). The unweighted pair group method using arithmetic averages (UPGMA) was used for cluster analysis (Sokal and Michener 1958).

\section{Results and discussion}

Identification of isolates and phylogenetic analysis by $16 \mathrm{~S}$ rDNA sequencing

Out of 20 field sediment samples, 40 Bacillus spp. were isolated. 16S rDNA was amplified by using universal primers and partially sequenced. In blastN search with the partial sequence of $16 \mathrm{~S}$ rDNA of all the isolates resulted to several hits having significant similarity with different Bacillus species. Percentage of similarity varied in between 97 and $100 \%$ (Table 1). Although comparison of the $16 \mathrm{~S}$ rRNA gene sequences has been useful in phylogenetic studies at the genus level, its use has been questioned in studies at the species level. The phylogenetic tree constructed from the $16 \mathrm{~S}$ rDNA sequence grouped all the isolates into three clusters (Fig. 1). Cluster I included all the strains of Bacillus subtilis and Bacillus amyloliquifaciens. Cluster II included all strains of Bacillus cereus and single isolate of Bacillus mycoids. Six strains of Bacillus pumilus, four strains of Bacillus altitudinis and single strain of Bacillus stratosphericus were grouped together in cluster III. Because closely related species may have identical 16S rRNA sequences or, alternatively, that divergent $16 \mathrm{~S}$ rRNA sequences may exist within a single organism (Stackebrandt and Goebel 1994). Ash et al. (1991) found the $16 \mathrm{~S}$ r DNA of B. anthracis, B. cereus,
Table 1 Sequence affiliation of Bacillus spp.

\begin{tabular}{|c|c|c|c|}
\hline $\begin{array}{l}\text { Strain } \\
\text { number }\end{array}$ & Identified organism & $\begin{array}{l}\text { Similarity } \\
(\%)^{\mathrm{a}}\end{array}$ & $\begin{array}{l}\text { Accession } \\
\text { number }\end{array}$ \\
\hline $\mathrm{C}_{2} \mathrm{~B}$ & Bacillus subtilis & 100 & HQ388813 \\
\hline $\mathrm{CF} 2$ & Bacillus cereus & 97 & JX438687 \\
\hline $\mathrm{C}_{8} \mathrm{M}$ & Bacillus pumilus & 100 & HQ388808 \\
\hline $\mathrm{C}_{11} \mathrm{~B}_{1}$ & Bacillus subtilis & 100 & HQ388810 \\
\hline $\mathrm{C}_{9} \mathrm{E}$ & Bacillus cereus & 100 & HQ388814 \\
\hline CF6 & Bacillus cereus & 99 & JX438686 \\
\hline CF7 & Bacillus cereus & 99 & JX438685 \\
\hline CF8 & Bacillus amyloliquifaciens & 99 & JX438692 \\
\hline CF9 & Bacillus altitudinis & 99 & JX438700 \\
\hline CF10 & Bacillus subtilis & 99 & JX438680 \\
\hline CF11 & Bacillus amyloliquifaciens & 99 & JX438693 \\
\hline CF12 & Bacillus stratosphericus & 99 & JX438704 \\
\hline CF13 & Bacillus altitudinis & 99 & JX438702 \\
\hline CF14 & Bacillus altitudinis & 99 & JX438701 \\
\hline CF15 & Bacillus altitudinis & 99 & JX438702 \\
\hline CF16 & Bacillus cereus & 99 & JX438688 \\
\hline CF17 & Bacillus cereus & 97 & JX438689 \\
\hline CF18 & Bacillus subtilis & 97 & JX438679 \\
\hline CF19 & Bacillus cereus & 99 & JX438690 \\
\hline CF20 & Bacillus pumilus & 97 & JX438699 \\
\hline $\mathrm{C}_{11} \mathrm{D}$ & Bacillus subtilis & 99 & HQ388812 \\
\hline $\mathrm{CF} 22$ & Bacillus subtilis & 97 & JX438681 \\
\hline CF23 & Bacillus subtilis & 99 & JX438682 \\
\hline CF24 & Bacillus subtilis & 99 & JX434683 \\
\hline CF25 & Bacillus subtilis & 99 & JX438684 \\
\hline CF26 & Bacillus pumilus & 99 & JX438698 \\
\hline $\mathrm{CF} 27$ & Bacillus pumilus & 99 & JX438697 \\
\hline $\mathrm{C}_{8} \mathrm{~K}_{1}$ & Bacillus subtilis & 99 & GQ214132 \\
\hline $\mathrm{C}_{1} \mathrm{G}$ & Bacillus subtilis & 100 & GQ214130 \\
\hline $\mathrm{C}_{1} \mathrm{H}$ & Bacillus cereus & 99 & GQ214131 \\
\hline $\mathrm{C}_{11} \mathrm{~B}_{2}$ & Bacillus subtilis & 99 & HQ388811 \\
\hline $\mathrm{C}_{11} \mathrm{E}$ & Bacillus cereus & 100 & HQ388815 \\
\hline $\mathrm{C}_{12} \mathrm{C}$ & Bacillus cereus & 100 & HQ388816 \\
\hline $\mathrm{C}_{11} \mathrm{C}$ & Bacillus cereus & 100 & HQ388817 \\
\hline CF36 & Bacillus cereus & 100 & JX438691 \\
\hline CF37 & Bacillus mycoides & 100 & JX438705 \\
\hline $\mathrm{C}_{5} \mathrm{~K}$ & Bacillus pumilus & 100 & HQ388809 \\
\hline CF39 & Bacillus pumilus & 99 & JX438694 \\
\hline CF40 & Bacillus pumilus & 99 & JX438695 \\
\hline CF41 & Bacillus pumilus & 99 & JX438696 \\
\hline
\end{tabular}

${ }^{\text {a }}$ Similarity $\%$ refers to the sequence similarity of $16 \mathrm{~S}$ rDNA between the study strains and the Bacillus type strains in the NCBI database

B. mycoides and B. thuringiensis to have almost complete sequence identity. Therefore, the present study was carried out to address two issues. Firstly, we explored the length polymorphisms of the 16S-23S rRNA intergenic spacer region at species level. Secondly, we compared ITS PCR 


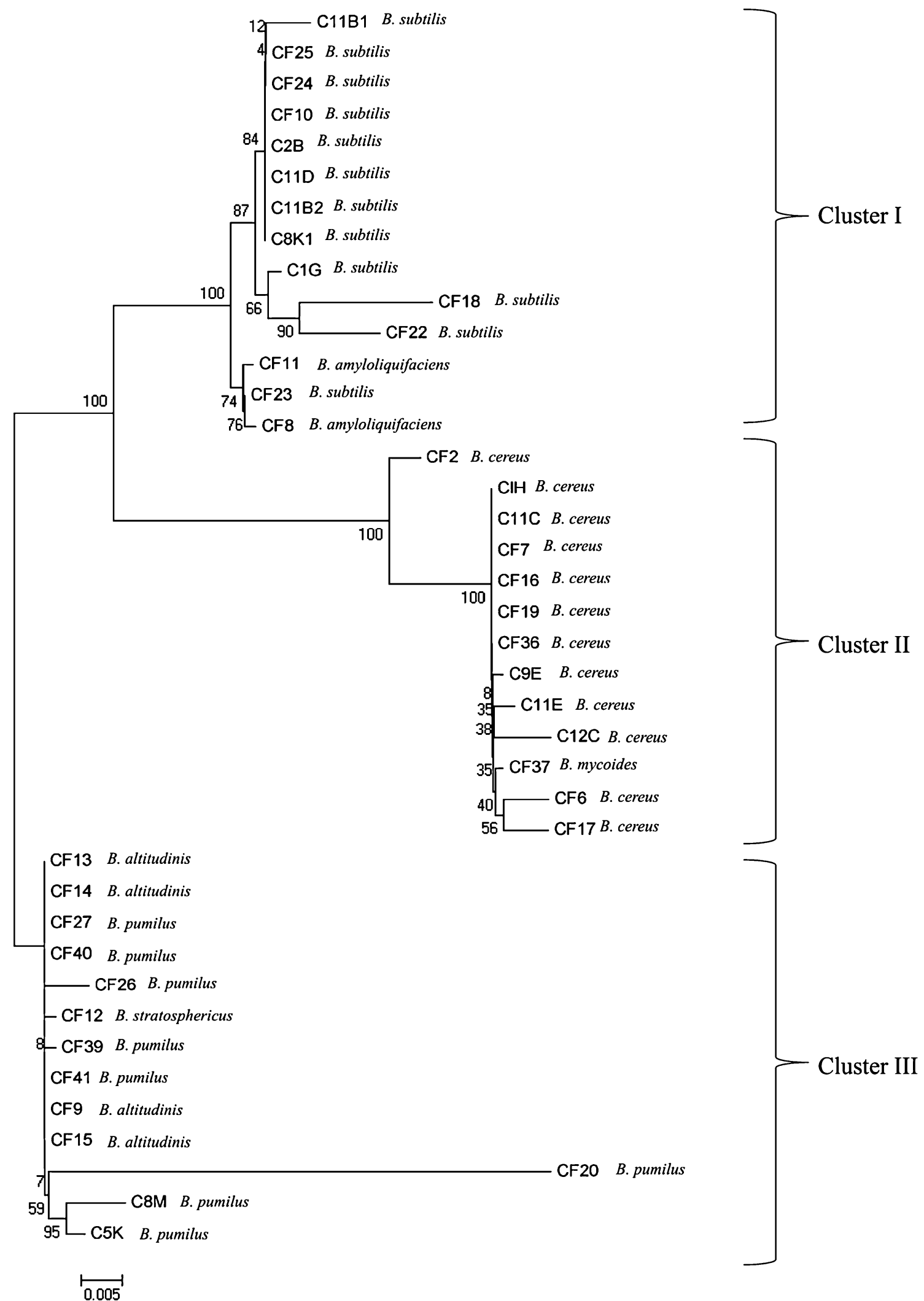

Fig. 1 Phylogenetic tree (unrooted) of partial 16S rRNA sequence of 40 isolates. The tree was constructed by Neighbor joining method using Mega program (Mega 5.05); bootstrap analysis was performed (bootstrap values are shown at the nodal branches) 
RFLP with PCR-RFLP of HSP60 gene for genomic analysis of Bacillus spp.

\section{ITS PCR-RFLP analysis}

To find out the genetic relationship among all the isolates Including ATCC strains ITS PCR-RFLP was carried out. The ITS region between $16 \mathrm{~S}$ and $23 \mathrm{~S}$ rRNA genes was amplified and digested with TaqI. By this technique 3-4 DNA fragments of 90-305 bp were observed in all the isolates (Fig. 2). Based on the number of fragments generated in each isolate different patterns were observed. In Bacillus subtilis four and Bacillus pumilus two patterns were observed. Bacillus amyloliquifaciens and Bacillus altitudinis showed one and two patterns respectively. Bacillus stratosphericus showed similar banding pattern to that of Bacillus subtilis. All the isolates of Bacillus cereus showed five different banding patterns. The banding pattern of Bacillus mycoides and Bacillus thuringiensis matched well with Bacillus cereus. The type strains of Bacillus subtilis, Bacillus cereus and Bacillus pumilus and other authentic strains of these species were not recovered in separate clusters. Dendrogram derived following numerical analysis of ITS PCR-RFLP data grouped the isolates in 11 clusters and one strain of Bacillus pumilus remained unclustered (Fig. 3). The clusters were defined as follows: when the maximum distance $\left(D_{\max }\right)$ between species rooted at a common node was less than 0.1, these species were classified in the same group. Cluster II, IV, V and XI were homogenous having strains of Bacillus megaterium, Bacillus licheniformis, Bacillus cereus and Bacillus subtilis, respectively. In other clusters 2-3 species were grouped together. Characteristic polymorphisms in the intergenic spacer (ITS) region often differentiate between closely related species, or even strains. (Gurtler and Stanisich 1996; Jensen et al. 1993). The intergenic spacer region of $16 \mathrm{~S}-23 \mathrm{~S}$ is often more variable than the gene itself and 16S-23S ISR may be useful area to investigate the genetic relationship of bacteria (Harrell et al. 1995). The ITS PCR-RFLP revealed clustering of same species in different group. This may be due to the heterogeneity of the ITS region among different strains of same species. Heterogeneity in the 23S-5S ISR region within single organism has also been observed in Saccharomonospora azurea K161T (Yoon et al. 1997). Although ITS PCR -RFLP is used for the phylogenetic analysis of Bacillus spp., it has some limitation regarding the newly diverge species (Wenner et al. 2002). It is likely that ITS PCR-RFLP is not always a reliable method for the phylogenetic analysis of Bacillus spp. as it cannot distinguish between very closely related species as demonstrated by DNA-DNA hybridization studies and comparison of bacterial rRNA or

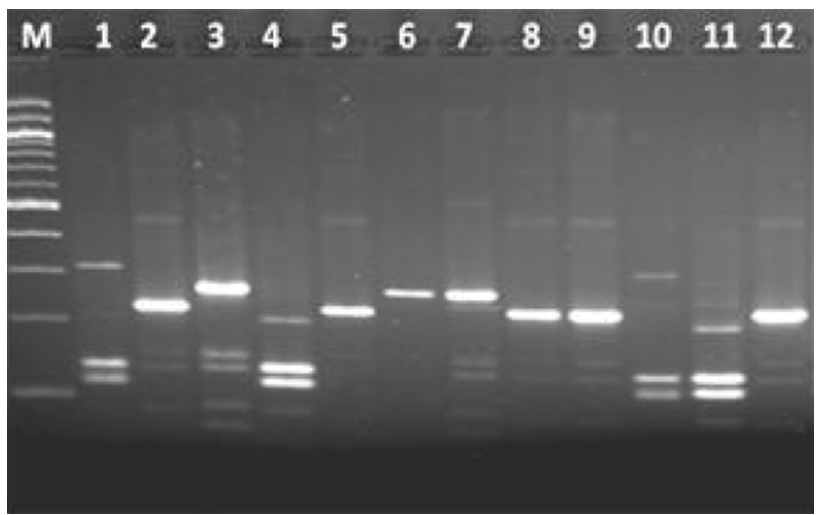

Fig. 2 RFLP of ITS-PCR digested with TaqI. Lane1-C1G (B. subtilis), Lane2-CF19 (B. cereus), Lane3-CF8 (B. amyloliquifaciens), Lane4-CF25 (B. subtilis), Lane5-CF7 (B. cereus), Lane6CF12 (B. stratosphericus), Lane7-C8M (B. pumilus), Lane8-CF13 (B. altitudinis), Lane9-CF9 (B. altitudinis), Lane10-C11B2 (B. subtiliss), Lane11-C11D (B. subtilis), Lane12-CF16 (B. cereus), LaneM-100 bp DNA ladder (NEB)

ribosomal DNA at the $16 \mathrm{~S}, 23 \mathrm{~S}$ and $16 \mathrm{~S}-23 \mathrm{~S}$ spacer regions (Chang et al. 2003).

\section{PCR-RFLP analysis of HSP60 gene}

Characterization based on PCR-RFLP of the HSP60 gene showed seventeen different banding patterns (Fig. 4), representing seventeen different genotype among all the strains, including the reference strains. Bacillus subtilis showed a single band of undigested product. Among eight strains of Bacillus pumilus, five showed similar banding pattern with fragment size of 380 and 370 bp (pattern D), except C5K, C8M and CF40 which showed three different banding patterns (pattern E, F and G, respectively). Pattern $\mathrm{H}(300,240$ and $220 \mathrm{bp})$, pattern I (600 and $150 \mathrm{bp})$, pattern $\mathrm{J}$ (350, 250 and $150 \mathrm{bp}$ ) and pattern Q (620 and $130 \mathrm{bp}$ ) included all the strains of Bacillus cereus. Four strains of Bacillus altitudinis showed a similar banding pattern having fragment size of 350, 300 and $100 \mathrm{bp}$ (pattern P). Bacillus mycoides (Pattern L) and Bacillus thuringiensis (Pattern $\mathrm{K}$ ) showed a different banding pattern compared to Bacillus cereus. The dendrogram constructed from HSP60 PCR RFLP data revealed 11 groups taking maximum distance $\left(D_{\max }\right)$ between species as 0.1 . Each of the ten clusters grouped only one type of species (Fig. 5) except Cluster I where a single strain of Bacillus stratosphericus is grouped together with Bacillus subtilis. The large majority of the isolates conformed exactly to those of the type strains. Studies on the suitability of a fragment from a conserved region of the HSP60 gene for phylogenetic analyses and speciation of the genera Staphylococcus and Macrococcus have been reported (Goh et al. 1996; Kwok and Chow 2003) and Bacteroides (Jian et al. 


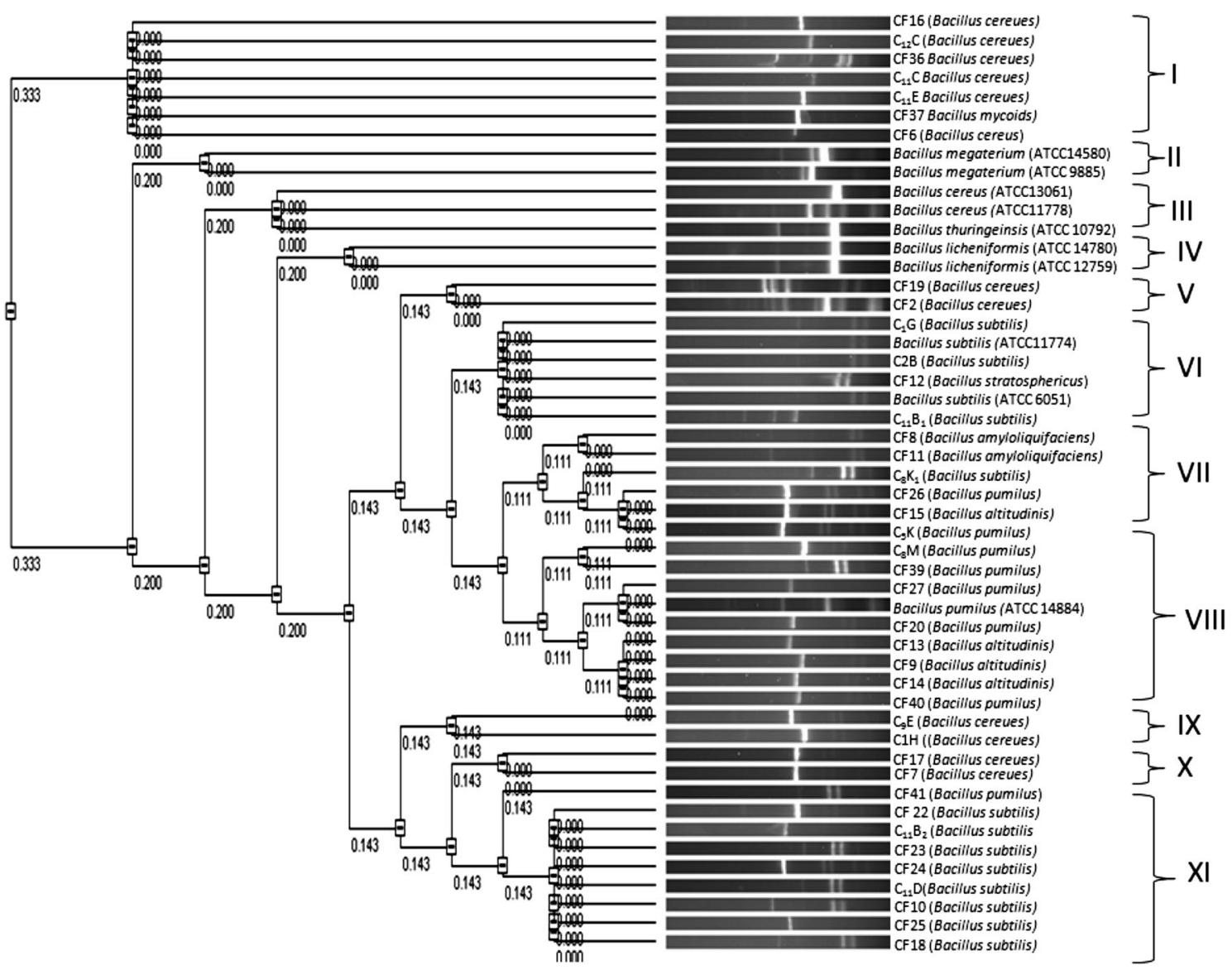

Fig. 3 RFLP analysis of partial ITS PCR amplicon digested with TaqI. The dendrogram was derived with VisionWorks ${ }^{\circledR}$ Life Science Software by using unweighted pair group method

2001). These studies have shown that, despite the conserved nature of the HSP60 gene, interspecies variation in the DNA sequences is greater than that in the corresponding 16S rRNA gene sequences, which may therefore provide better resolution for species classification (Mikkonen et al. 2004). HSP60 genes are ubiquitous in both prokaryotes and eucaryotes and encode highly conserved housekeeping proteins which are essential for survival of the bacteria and horizontal transmission of these genes may be as rare as that of rRNA genes. Thus, PCRRFLP analysis with the HSP60 gene is expected to provide higher resolution than one with PCR-RFLP of rRNA gene. In order to investigate the possible characterization of the Bacillus spp. through HSP60 gene the PCR-RFLP patterns were compared with ITS PCR-RFLP. Comparative analysis of PCR-RFLP of HSP60 and ITS PCR-RFLP revealed discrepancies in grouping pattern. The clustering of different species in the same cluster group as observed in ITS PCR RFLP was not observed in PCR-RFLP of HSP60 gene. Further, it was observed that Bacillus cereus and Bacillus mycoides, although they belong to same Bacillus cereus group were not discriminated by ITS PCR-RFLP

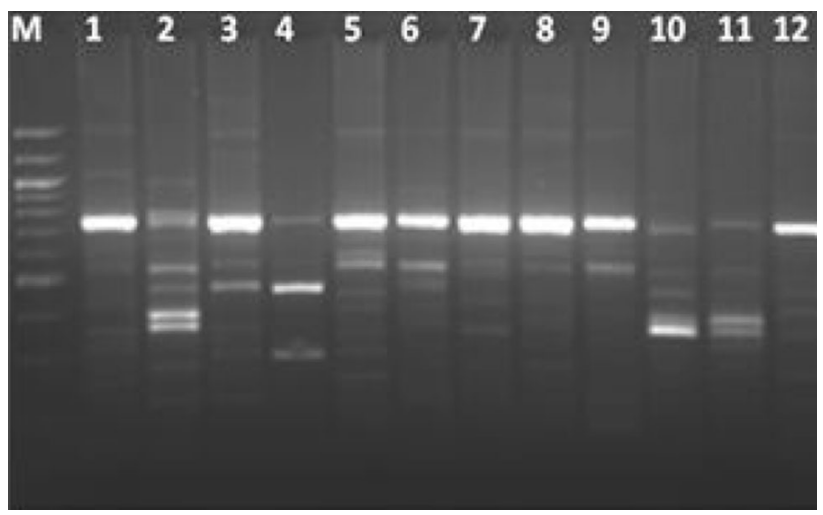

Fig. 4 RFLP of HSP60-PCR digested with PstI. Lane1-C1G (B. subtilis), Lane2-C8M (B. pumilus), Lane3-C11B2 (B. subtilis), Lane4-CF7 (B. cereus), Lane5-CF12 (B. stratosphericus), Lane6-CF8 (B. pumilus), Lane7-CF10 (B. subtilis), Lane8-C2B (B. subtilis), Lane9-CF11 (B. amyloliquifaciens), Lane10-CF13 (B. altitudinis), Lane11-CF9 (B. altitudinis), Lane12-CF25 (B. subtilis), LaneM-100 bp DNA ladder (NEB)

but PCR-RFLP of HSP60 gene clearly separated these two isolates. Similarly, in ITS PCR-RFLP all the isolates of Bacillus altitudinis showed different clustering pattern as 


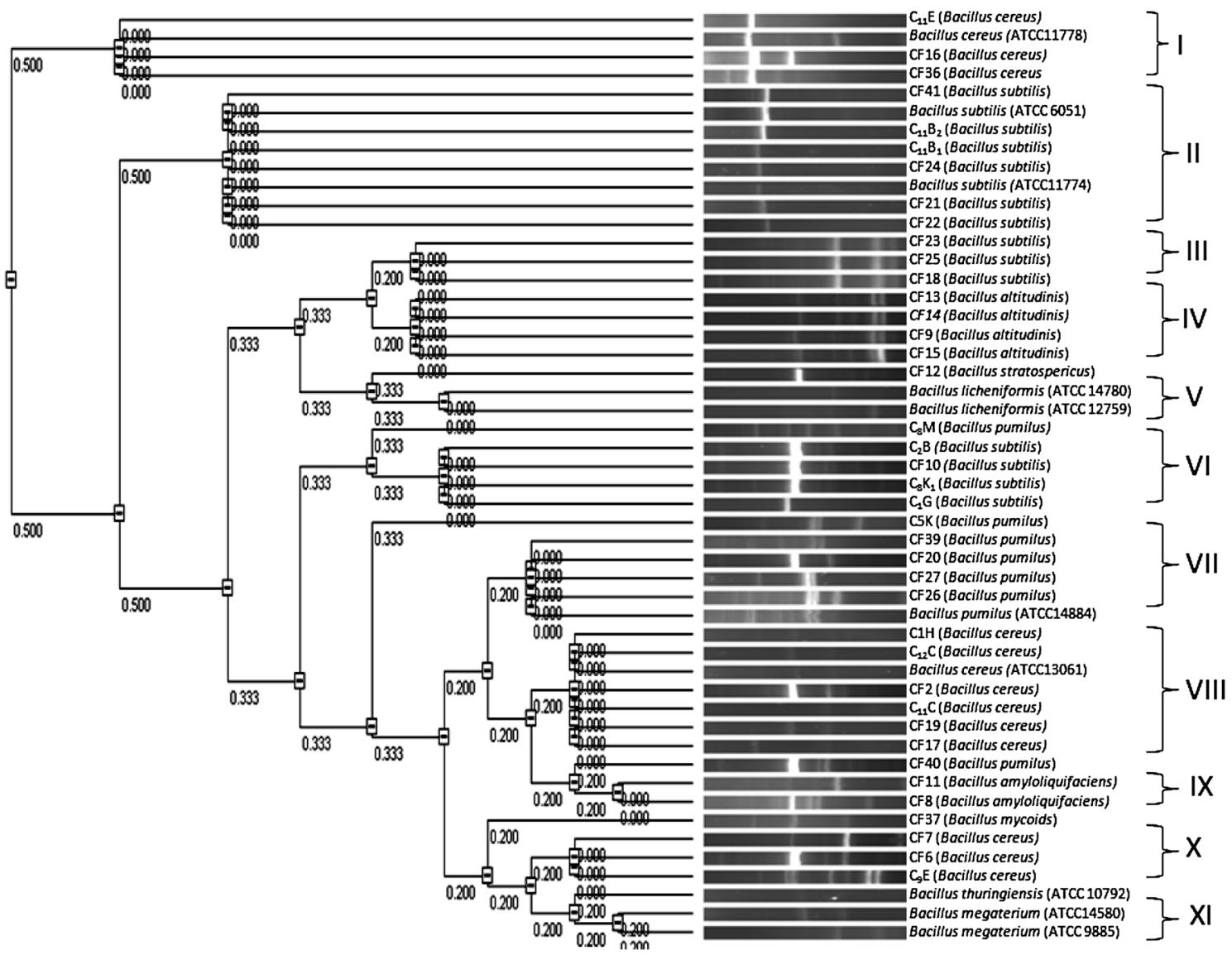

Fig. 5 RFLP analysis of partial 750 bp HSP60 gene amplicon digested with PstI. The dendrogram was derived with VisionWorks ${ }^{\circledR}$ Life Science Software by using unweighted pair group method

exemplified by clusters II and IX. Bacillus altitudinis (CF15) which was clustered with $B$ pumilus in ITS PCRRFLP was grouped together with isolates CF9, CF14 and CF13 by PCR-RFLP of HSP60 gene.

Comparative analysis of ITS PCR-RFLP, PCR-RFLP of HSP60 gene and 16S rDNA sequences revealed that $16 \mathrm{~S}$ rDNA sequences and ITS-PCR RFLP failed to separate the closely related species of Bacillus subtilis and Bacillus amyloliquifaciens, Bacillus cereus and Bacillus mycoides and Bacillus pumilus, Bacillus altitudinis and Bacillus stratosphericus. However, HSP60-PCR RFLP banding pattern distinctly separated these closely related species indicating more discriminatory power than $16 \mathrm{~S}$ rDNA sequences and ITS-PCR RFLP.

\section{Conclusion}

The present study has demonstrated that PCR-RFLP analysis of the HSP60 gene with PstI proved to be an adequate tool for the correct identification of Bacillus spp. and thus is technically less demanding than the majority of other molecular approaches. The method based on PCR-RFLP analysis of the HSP60 gene described here is able to increase considerably the list of species of genus Bacillus that could not be classified by PCR-RFLP analysis of other genes. However, the paucity of data on the divergence of the HSP60 sequence within Bacillus species makes it difficult to state whether this technique would not suffer the same criticism over the accurate identification of Bacillus at the species level as it was in the case of phylogenetic studies based on $16 \mathrm{~S}$ rRNA gene sequence analysis.

Acknowledgments The financial help received from NAIP, ICAR, New Delhi, India for carrying out the work is dully acknowledged.

Conflict of interest The authors declare that they have no conflict of interest.

Open Access This article is distributed under the terms of the Creative Commons Attribution License which permits any use, distribution, and reproduction in any medium, provided the original author(s) and the source are credited. 


\section{References}

Acinas SG, Klepac-Ceraj V, Hunt DE, Pharino C, Ceraj I, Distel DL, Polz MF (2004) Fine-scale phylogenetic architecture of a complex bacterial community. Nature 430:551-554

Ash C, Farrow JAE, Wallbanks S, Collins MD (1991) Phylogenetic heterogeneity of the genus Bacillus as revealed by comparative analysis of small-subunit-ribosomal RNA sequences. Lett Appl Microbiol 13:202-206

Banik S, Ninawe A (1988) Phosphate solubilising microorganism in water and sediments of a tropical estuary and the adjacent coastal Arabian Sea, in relation to their physic chemical properties. J Indian Soc Coast Agril Res 6:75-83

Chang Y-H, Shangkuan Y-H, Lin H-C, Lui H-W (2003) PCR assay of the groEL gene for detection and differentiation of Bacillus cereus group cells. Appl Environ Microbiol 69:4502-4510

Chen YP, Rekha PD, Arun AB, Shen FT, Lai W-A, Young CC (2006) Phosphate solubilizing bacteria from subtropical soil and their tricalcium phosphate solubilising abilities. Appl Soil Ecol 34:33-41

Clementino MM, Filippis ID, Nascimento Branquinho R, Rocha CL, Martins OB (2001) PCR analyses of tRNA intergenic spacer, 16S-23S internal transcribed spacer, and randomly amplified polymorphic DNA reveal inter- and intraspecific relationships of Enterobacter cloacae strains. J Clin Microbiol 39(11): 3865-3870

Dellaglio F, Dicks LMT, Dutoit M, Torriani S (1991) Designation of ATCC 334 in place of ATCC 393 (NCDO 161) as the neotype strain of Lactobacilluscasei subsp. casei and rejection of the name Lactobacillus paracasei. Int J Syst Bacteriol 41:340-342

Goh SW, Potter S, Wood JO, Hemmingsen SM, Reynolds RP, Chow WA (1996) HSP60 gene sequences as universal targets for microbial species identification: studies with coagulase-negative Staphylococci. J Clin Microbiol 34:818-823

Gurtler V, Stanisich VA (1996) New approaches to typing and identification of bacteria using the 16S-23S rDNA spacer region. Microbiology 142:3-16

Harrell LJ, Andersen GL, Wilson KH (1995) Genetic variability of Bacillus anthracis and related species. J Clin Microbiol 33:1847-1850

Jensen MA, Webster JA, Strausn N (1993) Rapid identification of bacteria on the basis of polymerase chain reaction-amplified ribosomal DNA spacer polymorphisms. Appl Environ Microbiol 59:945-952

Jian W, Zhu L, Dong X (2001) New approach to phylogenetic analysis of the genus Bifidobacterium based on partial HSP60 gene sequences. Int J Syst Evol Microbiol 51:1633-1638
Kwok AYC, Chow AW (2003) Phylogenetic study of Staphylococcus and Macrococcus species based on partial hsp60 gene sequences. Int J Syst Evol Microbiol 53:87-92

Mikkonen TP, Karenlampi RI, Hanninen M-L (2004) Phylogenetic analysis of gastric and enterohepatic Helicobacter species based on partial HSP60 gene sequences. Int J Syst Evol Microbiol 54:753-758

Nei M, Li WH (1979) Mathematical model for studying genetic variation in terms of restriction endonucleases. Proc Natl Acad Sci USA 76:5269-5273

Osorio CR, Collins MD, Romalde JL, Toranzo AE (2004) Characterization of the 23S and 5S rRNA genes and 23S-5S intergenic spacer region (ITS-2) of Photobacterium damselae. Dis Aquat Org 61:33-39

Rusanganwa E, Singh B, Gupta RS (1992) Cloning of HSP60 (GroEL) operon from Clostridium perfringens using a polymerase chain reaction based approach. Biochim Biophys Acta 1130(1):90-94

Sahu SN, Jana BB (2000) Enhancement of fertilizer value of rock phosphate engineered through phosphate solubilising bacteria. Ecol Eng 15:27-39

Schmalenberger A, Schwieger F, Tebbe CC (2001) Effects of primers hybridizing to different evolutionarily conserved regions of the small-subunit $r$ RNA gene in PCR-based microbial community analyses and gene profiling control. Appl Environ Microbiol 67:3557-3563

Sokal RR, Michener CD (1958) A statistical method for evaluating systematic relationships. Univ Kans Sci Bull 38:1409-1438

Stackebrandt E, Goebel BM (1994) Taxonomic note: a place for DNA- DNA reassociation and $16 \mathrm{~S}$ rRNA sequence analysis in the present species definition in bacteriology. Int J Syst Bacteriol 54:846-849

Stanley J, Baquar N, Burnens A (1995) Molecular subtyping scheme for Salmonella panama. J Clin Microbiol 33:1206-1211

Wenner T, Roth V, Decaris B, Leblond P (2002) Intragenomic and intraspecific polymorphism of the $16 \mathrm{~S}-23 \mathrm{~S}$ rDNA internally transcribed sequences of Streptomyces ambofaciens. Microbiology 148:633-642

Yoon J-H, Lee ST, Kim S-B, Goodfellow M, Park Y-H (1997) Interand intraspecific genetic analysis of the genus Saccharomonospora with $16 \mathrm{~S}$ to $23 \mathrm{~S}$ ribosomal DNA (rDNA) and $23 \mathrm{~S}$ to $5 \mathrm{~S}$ rDNA internally transcribed spacer sequences. Int $\mathrm{J}$ Syst Bacteriol 47:661-669

Yoon J-H, Kang K-H, Park Y-H (2003) Halobacillus salinus sp. nov., isolated from a salt lake on the coast of the East Sea in Korea. Int J Syst Evol Microbiol 53:687-693 